ENVIRONMENTAL EXPOSURE

\title{
Urinary cadmium levels predict lower lung function in current and former smokers: data from the Third National Health and Nutrition Examination Survey
}

\author{
D M Mannino, F Holguin, H M Greves, A Savage-Brown, A L Stock, R L Jones
}

Thorax 2004;59:194-198. doi: 10.1136/thorax.2003.012054

See end of article for authors' affiliations

Correspondence to: Dr D M Mannino, National Center for Environmental Health, Centers for Disease Control and Prevention 1600 Clifton Road, E-17 Atlanta, GA 30333, USÁ; dmannino@cdc.gov

Received 24 June 2003 Accepted 29 October 2003
Background: A study was undertaken to determine the relation between urinary cadmium levels and lung function in a nationally representative cohort of current, former, and never smokers in the US. Urinary cadmium levels reflect the total body burden of cadmium.

Methods: The following data from the Third National Health and Nutrition Examination Survey were analysed: urinary cadmium (adjusted for urinary creatinine), lung function, sex, race/ethnicity, age, education level, job category, body mass index, serum cotinine level, and smoking history. Linear regression models were developed to predict lung function using urinary cadmium as the main predictor, adjusting for other covariates and stratified by smoking status.

Results: Data were available on 16024 adults. Current smokers had higher mean (SE) urinary cadmium/ creatinine levels $(0.46(0.01) \mu \mathrm{g} / \mathrm{g})$ than former $(0.32(0.01) \mu \mathrm{g} / \mathrm{g})$ or never smokers $(0.23(0.01) \mu \mathrm{g} / \mathrm{g})$. Higher levels of urinary cadmium were associated with significantly lower forced expiratory volumes in 1 second $\left(\mathrm{FEV}_{1}\right)$ in current $(-2.06 \%, 95 \%$ confidence interval $(\mathrm{Cl})-2.86$ to -1.26 per 1 log increase in urinary cadmium) and former smokers $(-1.95 \%, 95 \% \mathrm{Cl}-2.87$ to -1.03$)$ but not in never smokers $(-0.18 \%, 95 \% \mathrm{Cl}-0.60$ to 0.24$)$. Similar results were obtained for forced vital capacity (FVC) and $\mathrm{FEV}_{1} /$ FVC.

Conclusions: Cadmium, which is known to cause emphysema in occupational settings, may also be important in the development of tobacco related lung disease.

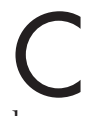
hronic obstructive pulmonary disease (COPD) is an important cause of morbidity and mortality throughout the world. ${ }^{12}$ A large proportion of people with impaired lung function have never been diagnosed with any lung disease, $^{3}$ suggesting that the true impact of COPD may be greatly underestimated.

Current understanding of the risk factors and pathogenesis of COPD remains incomplete. While smoking is the biggest known risk factor for developing COPD, not all smokers develop the disease. ${ }^{45}$ Other known risk factors for COPDincluding occupational exposure, air pollution, airway hyperresponsiveness, asthma, and genetic disease such as $\alpha_{1}$ antitrypsin deficiency —are also important. ${ }^{6-9}$ The mechanisms that make certain smokers more susceptible to developing COPD remain a subject of ongoing investigation. ${ }^{10-12}$

One toxicant in tobacco smoke that may be important in the development of COPD is cadmium. Cadmium has been linked to emphysema in occupationally exposed workers ${ }^{13} 14$ and has been shown to induce emphysema in laboratory animals. ${ }^{15}$ A recent review, however, stated that it seems "improbable that smoking induced emphysema could be attributed to cadmium". ${ }^{16}$

We examined the relationship between smoking, urinary cadmium levels, and pulmonary function in a nationally representative population using data from the National Health and Nutrition Examination Survey, 1988-1994 (NHANES III).

\section{METHODS}

\section{Study population}

NHANES III was conducted from 1988 to 1994 by the National Center for Health Statistics of the Centers for Disease Control and Prevention, Atlanta, Georgia. ${ }^{17}$ A stratified multistage clustered probability design was used to select a representative sample of the US population, yielding results that can be extrapolated to the non-institutionalised civilian US population. Study participants completed extensive questionnaires in the household and a comprehensive physical examination, including pulmonary function testing either in the household or at a specially equipped mobile examination centre. A total of 81 sites was included in the final sample. The study was approved by Institutional Review Board of the National Center for Health Statistics.

\section{Subjects and demographic characteristics}

Our study sample was limited to adult participants aged 17 years and older in NHANES III (1988-94) in whom pulmonary function tests were performed, urine cadmium and creatinine samples were taken, and who had data on sex, race/ethnicity, smoking status, occupation, and body mass index. Of the 20050 adult survey participants in NHANES III, 1888 did not have the examination, 1467 did not perform pulmonary function tests, urine samples were not obtained from 638, and in 33 there were missing data on other variables. After the exclusions, data were available from 16024 subjects for the main analysis. Excluded subjects were older and more likely to have fewer than 12 years of education than included subjects $(\mathrm{p}<0.05$ for both), but were similar in race/ethnicity, sex, and smoking status.

\section{Variable definitions}

The race of the participants was classified as white, black, Mexican-American or other and was determined by selfreport on the questionnaire. Other demographic covariates included were sex, education $(\leqslant 11$ years, 12 years, or $\geqslant 13$ years), and age. Subjects were stratified into six age strata; $17-24,25-44,45-64,65-74,75-84$, and $85+$ years. The body mass index was calculated by dividing the weight in $\mathrm{kg}$ by the square of the height in metres and classified as follows: 
$<18.5$, $\geqslant 18.5-24,25-29$, and $\geqslant 30 \mathrm{~kg} / \mathrm{m}^{2}$. ${ }^{18}$ Subjects were defined as current smokers, former smokers, pipe or cigar smokers, or never smokers based on their responses to a series of questions. Current pipe or cigar smokers were considered "current smokers". Subjects had to have smoked at least 100 cigarettes, 50 cigars, or 3 ounces of pipe tobacco to qualify as a former or current smoker. Data from the reported smoking history were used to calculate pack years of cigarettes smoked and, for former smokers, years since they stopped smoking. Subjects were asked what occupation they had worked in for the longest period of time and this was classified into one of six categories: agriculture, mining/ manufacturing, transportation, service, other/unemployed, and retail. Subjects reported their average monthly intake of dairy products, vegetables, fruits, meats, and grains.

\section{Pulmonary function data}

Using either a dry rolling seal spirometer in the mobile examination centre ( $98.5 \%$ of included subjects) or a portable spirometer in the home, spirometric tests were conducted on the participating subjects. Procedures for testing were based on the 1987 American Thoracic Society recommendations. ${ }^{19}$ In order to obtain curves acceptable according to the protocol, subjects performed 5-8 forced expirations. They were excluded from the analysis if they either did not perform spirometric tests or had results that were not reliable. Values used in this analysis included forced vital capacity (FVC), forced expiratory volume in 1 second $\left(\mathrm{FEV}_{1}\right)$, and the $\mathrm{FEV}_{\mathrm{l}}$ / FVC ratio. Predicted values of $\mathrm{FEV}_{1}$ and FVC were determined using previously published prediction equations. ${ }^{20}$ The sex specific model for white participants was applied to people of "other" race. Criteria from the Global Initiative on Obstructive Lung Disease (GOLD) were used to define subjects with stage 2 or worse COPD $\left(\mathrm{FEV}_{1} / \mathrm{FVC}<0.70\right.$ and $\mathrm{FEV}_{1}<80 \%$ predicted). ${ }^{21}$

\section{Urine samples}

Participants provided urine samples in either the home or mobile examination centre. Urine cadmium and creatinine measurements were included in the analysis. Cadmium levels were measured by graphite furnace atomic absorption spectrophotometry at the Centers for Disease Control and Prevention laboratory. ${ }^{22}$ The limit of detection was $0.03 \mu \mathrm{g} / \mathrm{l}$; subjects with levels below the limit of detection were assigned a level of $0.01 \mu \mathrm{g} / \mathrm{l}$. Cadmium levels were below the level of detection in $6.8 \%$ of the urine samples. Cadmium levels were adjusted for the urine creatinine concentration ${ }^{23}$ and the natural logarithm of these levels was used in the analyses because of a skewed distribution.

\section{Cotinine levels}

Serum cotinine levels were determined using high performance liquid chromatography atmospheric pressure chemical ionisation tandem mass spectrometry as described elsewhere. ${ }^{24}$ The study population was stratified into five groups on the basis of cotinine levels: below the limit of detection of $0.050 \mathrm{ng} / \mathrm{ml}$ (no smoke exposure), 0.050-0.29 ng/ml (low smoke exposure), 0.29-14.9 ng/ml (high smoke exposure), $15-99 \mathrm{ng} / \mathrm{ml}$ (light smoker), and $\geqslant 100 \mathrm{ng} / \mathrm{ml}$ (moderate/ heavy smoker).

\section{Analysis of data}

All estimates were calculated using the sampling weight to represent adults aged 17 years and older in the US. The purpose of these sampling weights was to adjust for unequal probabilities of selection and to account for non-response. All percentages shown are weighted and age adjusted to the distribution of participants in the final analytical sample.

Multivariate linear regression models were developed to describe the predictors of the urine cadmium/creatinine levels and to define the relation between measures of lung function and the urine cadmium/creatinine level, stratified by smoking status. We also used logistic regression models to predict subjects who met GOLD stage 2 or higher criteria for COPD (compared with subjects with normal lung function). Multivariate models adjusted for age, sex, race, body mass index, education level, cotinine level, pack years of cigarettes, and years since smoking cessation (for former smokers). Models were evaluated for interaction. SAS and SUDAAN, a program that adjusts for the complex sample design when calculating variance estimates, were used for the analysis. ${ }^{25} 26$

\section{RESULTS}

Creatinine adjusted urine cadmium levels were higher in smokers and increased with age (table 1, fig 1). Linear regression models for log urine cadmium/creatinine showed that higher age, black or Mexican-American race/ethnicity, and female sex were associated with higher levels in all three smoking categories (table 2). Indicators of smoking status (pack years for current smokers, years since smoking cessation for former smokers, and cotinine levels for all three categories) were also significant predictors of the urine cadmium/creatinine level (table 2). Working in the mining/ manufacturing or transportation fields was associated with higher levels in current and former smokers (table 2). These levels also varied dramatically among smokers with similar smoking histories. For example, among 71 current smokers aged 50-60 years with a 40-50 pack year history the median urine cadmium/creatinine level was $1.3 \mu \mathrm{g} / \mathrm{g}$ with $10 \%$ having levels $>2.2 \mu \mathrm{g} / \mathrm{g}$ and $10 \%$ having levels $<0.6 \mu \mathrm{g} / \mathrm{g}$.

The age adjusted measures of lung function (percentage predicted $\mathrm{FEV}_{1}$, percentage predicted $\mathrm{FVC}$, and $\mathrm{FEV}_{1} / \mathrm{FVC}$ ) also varied with covariates. As expected, current smokers had

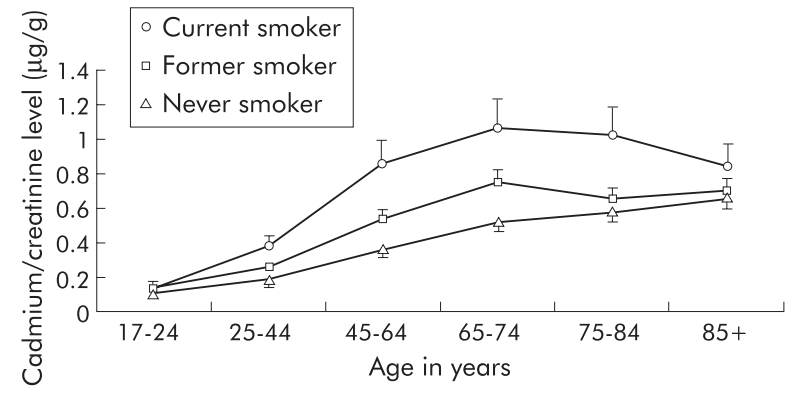

Figure 1 Geometric mean creatinine adjusted urine cadmium levels stratified by smoking status. From the Third National Health and Nutrition Examination Survey, 1988-94.

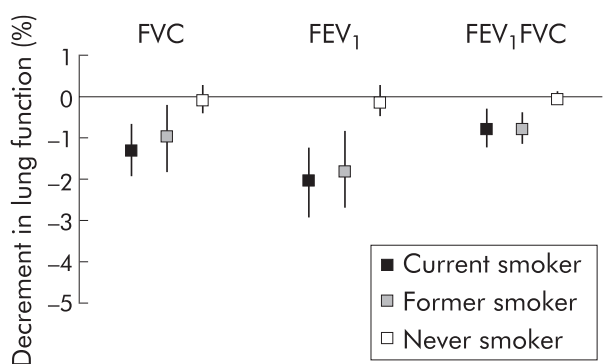

Figure 2 Decrease in lung function for a one log increase in urine cadmium/creatinine level for forced vital capacity (FVC), forced expiratory volume in 1 second $\left(\mathrm{FEV}_{1}\right)$, and $\mathrm{FEV}_{1} \mathrm{FVC}$ ratio, stratified by smoking status. Results from linear regression models adjusted for age, race, sex, education level, job category, body mass index, pack years of smoking, cotinine level, and years since regular cigarette smoking. From the Third National Health and Nutrition Examination Survey, 1988-1994. 
Table 1 Study population stratified by covariates with the weighted proportion in each stratum, the age adjusted geometric mean urine cadmium/creatinine level, and age adjusted forced expiratory volume in 1 second (FEV 1 )/ forced vital capacity (FVC) ratio for each stratum

\begin{tabular}{|c|c|c|c|c|}
\hline Variable & $\mathrm{N}$ & Weighted \% & $\begin{array}{l}\text { Geometric mean (SE) urinary } \\
\text { cadmium/creatinine level } \\
(\mu \mathrm{g} / \mathrm{g})\end{array}$ & $\begin{array}{l}\text { Mean (SE) } \\
\mathrm{FEV}_{1} / \text { FVC (\%) }\end{array}$ \\
\hline \multicolumn{5}{|l|}{ Age } \\
\hline $85+$ & 290 & 0.7 & $0.68(0.03)$ & $72.6(0.7)$ \\
\hline $75-84$ & 1212 & 4.1 & $0.64(0.03)$ & $71.1(0.4)$ \\
\hline $65-74$ & 1878 & 9.0 & $0.69(0.02)$ & $71.1(0.4)$ \\
\hline $45-64$ & 3762 & 25.0 & $0.53(0.02)$ & $75.0(0.2)$ \\
\hline $25-44$ & 6135 & 44.9 & $0.25(0.01)$ & $80.8(0.2)$ \\
\hline $17-24$ & 2747 & 16.4 & $0.11(0.01)$ & $85.3(0.2)$ \\
\hline \multicolumn{5}{|l|}{ Race/ethnicity } \\
\hline White & 6469 & 76.2 & $0.30(0.01)$ & $78.3(0.2)$ \\
\hline Black & 4509 & 10.9 & $0.36(0.01)$ & $80.4(0.2)$ \\
\hline Mexican-American & 4410 & 5.3 & $0.31(0.01)$ & $80.7(0.2)$ \\
\hline Other & 636 & 7.7 & $0.34(0.02)$ & $80.4(0.4)$ \\
\hline \multicolumn{5}{|l|}{ Sex } \\
\hline Male & 7541 & 48.2 & $0.26(0.01)$ & $77.4(0.2)$ \\
\hline Female & 8483 & 51.8 & $0.36(0.01)$ & $80.0(0.2)$ \\
\hline \multicolumn{5}{|l|}{ Education level (years) } \\
\hline$<12$ & 6727 & 25.6 & $0.37(0.01)$ & $78.5(0.3)$ \\
\hline 12 & 4582 & 31.0 & $0.33(0.02)$ & $78.5(0.2)$ \\
\hline$\geqslant 13$ & 4715 & 43.5 & $0.26(0.01)$ & $79.1(0.2)$ \\
\hline \multicolumn{5}{|l|}{ Job category } \\
\hline Agriculture & 1456 & 5.9 & $0.27(0.02)$ & $77.9(0.4)$ \\
\hline Mining/manufacturing & 3735 & 24.3 & $0.32(0.01)$ & $78.3(0.3)$ \\
\hline Transport & 776 & 5.6 & $0.35(0.02)$ & $77.6(0.5)$ \\
\hline Service & 5883 & 39.1 & $0.30(0.01)$ & $79.2(0.2)$ \\
\hline Unemployed & 1285 & 6.1 & $0.34(0.02)$ & $78.6(0.4)$ \\
\hline Retail & 2889 & 19.1 & $0.30(0.01)$ & $79.1(0.2)$ \\
\hline \multicolumn{5}{|l|}{ Smoking status } \\
\hline Current smoker & 4321 & 30.0 & $0.46(0.01)$ & $76.5(0.2)$ \\
\hline Former smoker & 3592 & 23.4 & $0.32(0.01)$ & $78.1(0.3)$ \\
\hline Never smoker & 8111 & 46.6 & $0.23(0.01)$ & $80.7(0.2)$ \\
\hline \multicolumn{5}{|l|}{ Body mass index $\left(\mathrm{kg} / \mathrm{m}^{2}\right)$} \\
\hline$<18.5$ & 358 & 2.5 & $0.44(0.03)$ & $78.3(1.1)$ \\
\hline $18.5-24$ & 6282 & 44.2 & $0.30(0.01)$ & $78.4(0.2)$ \\
\hline $25-29$ & 5416 & 31.6 & $0.31(0.01)$ & $78.3(0.2)$ \\
\hline$\geqslant 30$ & 3968 & 21.6 & $0.31(0.01)$ & $79.2(0.3)$ \\
\hline \multicolumn{5}{|l|}{ Years ago quit smoking } \\
\hline$>0-10$ & 1516 & 10.5 & $0.37(0.01)$ & $77.5(0.4)$ \\
\hline$>10-20$ & 939 & 6.2 & $0.33(0.02)$ & $76.8(0.3)$ \\
\hline$>20-30$ & 533 & 3.4 & $0.27(0.02)$ & $74.9(1.3)$ \\
\hline$>30-40$ & 236 & 1.2 & $0.40(0.05)$ & $74.3(0.7)$ \\
\hline$>40$ & 210 & 0.9 & $0.40(0.06)$ & $76.8(1.2)$ \\
\hline Not applicable & 12590 & 77.9 & $0.31(0.01)$ & $79.0(0.1)$ \\
\hline \multicolumn{5}{|l|}{ Pack years of cigarettes } \\
\hline$\geqslant 60$ & 597 & 3.8 & $0.61(0.05)$ & 73.7 (1.7) \\
\hline$\leqslant 30-59$ & 1190 & 8.5 & $0.54(0.02)$ & $77.4(0.3)$ \\
\hline$>0-29$ & 5886 & 39.6 & $0.36(0.01)$ & $78.2(0.2)$ \\
\hline 0 & 8351 & 48.0 & $0.23(0.01)$ & $80.6(0.1)$ \\
\hline \multicolumn{5}{|l|}{ Cotinine level (ng/ml) } \\
\hline$>100$ & 3415 & 25.4 & $0.50(0.02)$ & $76.1(0.2)$ \\
\hline$\leqslant 15-100$ & 1004 & 5.6 & $0.28(0.02)$ & $78.2(0.4)$ \\
\hline$\leqslant 0.3-15$ & 3876 & 22.5 & $0.27(0.02)$ & $79.6(0.2)$ \\
\hline $0.05-0.29$ & 5114 & 31.9 & $0.26(0.01)$ & $79.7(0.2)$ \\
\hline Non-detectable & 1771 & 10.3 & $0.22(0.02)$ & $80.1(0.3)$ \\
\hline Missing & 844 & 4.3 & $0.30(0.02)$ & $79.3(0.4)$ \\
\hline Total & 16024 & 100.0 & $0.31(0.01)$ & $78.7(1.1)$ \\
\hline
\end{tabular}

a lower percentage predicted $\mathrm{FEV}_{1}(91.4(0.4) v 97.8(0.4))$

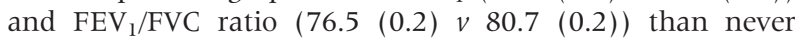
smokers (table 1).

Among current and former smokers, higher levels of urinary cadmium were associated with significantly lower values of $\mathrm{FEV}_{1}, \mathrm{FVC}$, and $\mathrm{FEV}_{\mathrm{l}} / \mathrm{FVC}$ ratio in models that adjusted for age, race, sex, education level, job category, body mass index, cotinine level, pack years of smoking, and years since regular smoking (for former smokers) (fig 2 and supplementary tables S1-3 shown on the Thorax website at www.thoraxjnl.com/supplemental). For example, among the 50-60 year old current smokers with a smoking history of 4050 pack years, the mean decrease in $\mathrm{FEV}_{1}$ in subjects in the 90th percentile of urine cadmium level compared with those in the 10th percentile was $3.2 \%$. There was no significant relation between urine cadmium levels and lung function among never smokers (fig 2 and supplementary tables S1-3)

Logistic regression models showed that, after adjusting for covariates, a higher urine cadmium/creatinine level was associated with GOLD stage 2 or higher COPD in current smokers (odds ratio (OR) 2.29, 95\% confidence interval (CI) 1.67 to 3.15 ) and former smokers (OR 1.90, 95\% CI 1.38 to 2.63 ) but not in never smokers (OR $1.25,95 \%$ CI 0.98 to 1.60 ) (table S4 available on the Thorax website at www.thoraxjnl. com/supplemental).

\section{DISCUSSION}

In a representative US population higher levels of urinary cadmium were found to be significant predictors of lower $\mathrm{FVC}, \mathrm{FEV}_{1}$, and $\mathrm{FEV}_{1} / \mathrm{FVC}$ in current and former smokers but 
Table 2 Results of regression models for log urine cadmium/creatinine adjusted for age, race/ethnicity, sex, education, job category, body mass index, years ago quit smoking (for former smokers), pack years of cigarettes, cotinine level, and daily intake of dairy products, fruits, vegetables, meats and grains

\begin{tabular}{|c|c|c|c|}
\hline Variable & Current smokers & Former smokers & Never smokers \\
\hline Intercept & $-3.68(-4.30$ to -3.06$)$ & $-2.62(-2.96$ to -2.28$)$ & $-2.90(-3.12$ to -2.68$)$ \\
\hline Age (10 years) & $0.38(0.36$ to 0.40$)$ & $0.32(0.30$ to 0.34$)$ & $0.31(0.29$ to 0.33$)$ \\
\hline \multicolumn{4}{|l|}{ Race/ethnicity } \\
\hline White & 0 & 0 & 0 \\
\hline Black & 0.15 (0.07 to 0.23$)$ & $0.12(0.02$ to 0.22$)$ & $0.28(0.14$ to 0.42$)$ \\
\hline Mexican-American & $0.14(0.00$ to 0.28$)$ & $0.13(0.01$ to 0.25$)$ & $0.35(0.23$ to 0.47$)$ \\
\hline Other & $0.20(0.00$ to 0.40$)$ & $0.17(-0.01$ to 0.35$)$ & $0.32(0.14$ to 0.50$)$ \\
\hline \multicolumn{4}{|c|}{ (1) } \\
\hline Male & $-0.33(-0.41$ to -0.25$)$ & $-0.42(-0.50$ to -0.34$)$ & $-0.58(-0.66$ to -0.50$)$ \\
\hline Female & 0 & 0 & 0 \\
\hline \multicolumn{4}{|l|}{ Education level (years) } \\
\hline$<12$ & $0.17(0.05$ to 0.29$)$ & $0.03(-0.09$ to 0.15$)$ & $-0.01(-0.11$ to 0.09$)$ \\
\hline 12 & $0.17(0.07$ to 0.27$)$ & $0.06(-0.04$ to 0.16$)$ & $-0.02(-0.14$ to 0.10$)$ \\
\hline$\geqslant 13$ & 0 & 0 & 0 \\
\hline \multicolumn{4}{|l|}{ Job category } \\
\hline Agriculture & $0.03(-0.17$ to 0.23$)$ & $-0.06(-0.22$ to 0.10$)$ & $-0.01(-0.19$ to 0.17$)$ \\
\hline Mining/manufacturing & $0.21(0.05$ to 0.37$)$ & $0.15(0.03$ to 0.27$)$ & $0.10(-0.04$ to 0.24$)$ \\
\hline Transport & $0.27(0.07$ to 0.47$)$ & $0.17(0.05$ to 0.29$)$ & $0.12(-0.10$ to 0.34$)$ \\
\hline Service & $0.09(-0.05$ to 0.23$)$ & $0.03(-0.11$ to 0.17$)$ & $0.03(-0.09$ to 0.15$)$ \\
\hline Unemployed & $0.17(-0.03$ to 0.37$)$ & $0.06(-0.14$ to 0.26$)$ & $0.02(-0.12$ to 0.16$)$ \\
\hline Retail & 0 & 0 & 0 \\
\hline \multicolumn{4}{|l|}{ Body mass index $\left(\mathrm{kg} / \mathrm{m}^{2}\right)$} \\
\hline$<18.5$ & $0.03(-0.19$ to 0.25$)$ & $-0.25(-0.75$ to 0.25$)$ & $0.08(-0.24$ to 0.40$)$ \\
\hline $18.5-24$ & & 0 & \\
\hline $25-29$ & $0.08(0.00$ to 0.16$)$ & $0.03(-0.07$ to 0.13$)$ & 0.09 (0.01 to 0.17$)$ \\
\hline$\geqslant 30$ & $-0.05(-0.13$ to 0.03$)$ & $0.05(-0.07$ to 0.17$)$ & $0.04(-0.06$ to 0.14$)$ \\
\hline \multicolumn{4}{|c|}{ Years ago quit smoking cigarettes } \\
\hline$>0-10$ & & $0.54(0.36$ to 0.72$)$ & \\
\hline$>10-20$ & & $0.29(0.11$ to 0.47$)$ & \\
\hline$>20-30$ & & $0.20(0.00$ to 0.40$)$ & \\
\hline$>30-40$ & & $0.11(-0.11$ to 0.33$)$ & \\
\hline$>40$ & & 0 & \\
\hline Unknown & & $0.53(0.31$ to 0.75$)$ & \\
\hline \multicolumn{4}{|l|}{$\begin{array}{l}\text { Unknown } \\
\text { Pack years of cigarettes }\end{array}$} \\
\hline$\geqslant 60$ & $0.59(0.27$ to 0.91$)$ & $0.24(0.00$ to 0.48$)$ & \\
\hline$\leqslant 30-59$ & $0.61(0.37$ to 0.85$)$ & $0.14(-0.08$ to 0.36$)$ & \\
\hline$>0-29$ & $0.43(0.21$ to 0.65$)$ & $-0.26(-0.50$ to -0.02$)$ & \\
\hline 0 & 0 & 0 & \\
\hline \multicolumn{4}{|l|}{ Cotinine level $(\mathrm{ng} / \mathrm{ml})^{*}$} \\
\hline$>100$ & 0.93 (0.33 to 1.53 ) & $0.23(0.03$ to 0.43$)$ & $0.34(0.14$ to 0.54$)$ \\
\hline$\leqslant 15-100$ & $0.31(-0.31$ to 0.93$)$ & $0.04(-0.28$ to 0.36$)$ & $0.15(-0.13$ to 0.43$)$ \\
\hline$\leqslant 0.3-15$ & $0.20(-0.44$ to 0.84$)$ & $0.16(0.02$ to 0.30$)$ & 0.26 (0.14 to 0.38 ) \\
\hline $0.05-0.29$ & $0.08(-0.62$ to 0.78$)$ & $0.15(0.01$ to 0.29$)$ & $0.18(0.04$ to 0.32$)$ \\
\hline Non-detectable & 0 & 0 & 0 \\
\hline Missing & $0.82(0.22$ to 1.42$)$ & $0.08(-0.18$ to 0.34$)$ & $0.09(-0.11$ to 0.29$)$ \\
\hline \multicolumn{4}{|l|}{ Dietary factors } \\
\hline Dairy intake & $0.00(-0.04$ to 0.04$)$ & $-0.06(-0.10$ to -0.02$)$ & $0.00(-0.04$ to 0.04$)$ \\
\hline Fruit intake & $-0.01(-0.03$ to 0.01$)$ & $-0.01(-0.03$ to 0.01$)$ & $-0.01(-0.03$ to 0.01$)$ \\
\hline Vegetable intake & $0.08(0.06$ to 0.10$)$ & $0.01(-0.03$ to 0.05$)$ & $0.02(0.00$ to 0.04$)$ \\
\hline Meat intake & $-0.05(-0.11$ to 0.01$)$ & $-0.02(-0.08$ to 0.04$)$ & 0.05 (0.01 to 0.09 ) \\
\hline Grain intake & $-0.02(-0.06$ to 0.02$)$ & $-0.02(-0.06$ to 0.02$)$ & $-0.05(-0.07$ to -0.03$)$ \\
\hline$r^{2}$ of model & 0.41 & 0.39 & 0.30 \\
\hline
\end{tabular}

Data are presented as regression coefficients with $95 \%$ confidence intervals.

*Some never and former smokers had cotinine levels $>15 \mathrm{ng} / \mathrm{ml}$, suggesting misclassification of smoking status.

From the Third National Health and Nutrition Examination Survey, 1988-94.

not in never smokers. In addition, variability in urine cadmium levels was found among current smokers. It is not clear whether this finding is related to the dose of cadmium to which smokers are exposed or to variability in the uptake and metabolism of cadmium in smokers. It is possible that the variability in cadmium levels in smokers is related to the intensity of smoking - that is, smokers with higher cadmium levels extract more tar and nicotine out of each cigarette than smokers with lower levels. It is also possible that the variability in lung function in smokers is similarly related to variability in smoking intensity, and that cadmium levels are just a long term marker of tobacco dose.

Cadmium intake in humans is either through ingestion or inhalation, with the major source of exposure in never smokers being ingestion and in smokers being inhalation. ${ }^{27}$ The differences we observed-with significant decreases in lung function occurring only in current and former smokers-may be because urinary cadmium levels reflect lung cadmium better in smokers than in never smokers. ${ }^{28}$

One cigarette contains about $2 \mu \mathrm{g}$ cadmium, $2-10 \%$ of which is transferred to primary cigarette smoke. ${ }^{29}$ Data from the Massachusetts Benchmark Study showed considerable variation in the cadmium content of mainstream smoke from 27 brands of tested cigarettes, ranging from 31 to $222 \mathrm{ng} /$ cigarette with a median level of $137 \mathrm{ng} /$ cigarette. ${ }^{30}$ Smokers have previously been shown to have higher blood and urinary cadmium levels ${ }^{22}{ }^{31} 32$ as well as higher lung tissue cadmium levels. ${ }^{33-35}$ Urinary cadmium levels have been found to correlate closely with lung cadmium levels in current and former smokers. ${ }^{28}$ Urinary levels of cadmium rise with renal dysfunction $^{36}{ }^{37}$ and need to be adjusted accordingly. Adjustment of urinary cadmium to creatinine reduces variability between individuals. ${ }^{23}$ Cadmium levels in the lung and urine remain raised for many years after smoking cessation. ${ }^{22}{ }^{34}$ 
Cadmium damages pulmonary cells in vitro, affecting several levels of function including repair of DNA, ${ }^{38}$ cellular enzyme activity and membrane structure, ${ }^{39}$ and $\alpha_{1}$-antitrypsin inhibitory capacity. ${ }^{40}$ Cadmium has been shown to be associated with the development of emphysema in occupationally exposed cohorts, ${ }^{13}$ although its role in the development of lung cancer is less clear. ${ }^{41-43}$

Bjorkman et al found that up to $10 \%$ of the variability in cadmium concentrations was related to genetic factors. ${ }^{44}$ The expression and regulation of metallothionein proteins, which absorb and sequester cadmium and protect against cadmium toxicity, ${ }^{45}$ may be part of the mechanism of genetic variation observed in cadmium uptake and metabolism.

This study is subject to some limitations. Because it is cross sectional in design, we cannot say that higher cadmium levels led to lower lung function. Smoking status and smoking histories were self-reported, with the potential for misclassification of these critically important measures. Occupational or non-vocational exposures to cadmium (such as alloy making, jewellery making, etc) were not specifically asked about.

In conclusion, we found that urinary cadmium levels, which reflect the total body burden of cadmium, are inversely associated with lung function in current and former smokers but not in never smokers. Future research should examine whether lung cadmium levels are predictors of lung function decline, the extent to which variation in cadmium levels among smokers reflects cadmium dose versus cadmium uptake and metabolism, and whether increased levels of cadmium in the lung are amenable to intervention.

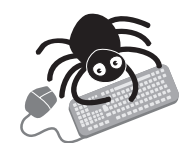

Supplementary tables S1-4 are available on the Thorax website at www.thoraxinl.com/supplemental.

\section{Authors' affiliations}

D M Mannino, F Holguin, H M Greves, A Savage-Brown, A L Stock, Air

Pollution and Respiratory Health Branch, Division of Environmental Hazards and Health Effects, Atlanta, Georgia, USA

R L Jones, Division of Laboratory Sciences, National Center for Environmental Health, Centers for Disease Control and Prevention, Atlanta, Georgia, USA

\section{REFERENCES}

1 Mannino DM, Homa DM, Akinbami L, et al. Surveillance for chronic obstructive pulmonary disease - United States, 1971-2000. MMWR CDC Surveillance Summaries 2002;50.

2 Chen JC, Mannino DM. Worldwide epidemiology of chronic obstructive pulmonary disease. Curr Opin Pulm Med 1999;5:93-9.

3 Mannino DM, Gagnon RC, Petty TL, et al. Obstructive lung disease and low lung function in adults in the United States: data from the National Health and Nutrition Examination Survey, 1988-1994. Arch Intern Med 2000;160:1683-9.

4 Rennard SI. COPD: overview of definitions, epidemiology, and factors influencing its development. Chest 1998;113:235-41S.

5 Lundback B, Lindberg A, Lindstrom $M$, et al. Not 15 but $50 \%$ of smokers develop COPD? Report from the Obstructive Lung Disease in Northern Sweden Studies. Respir Med 2003;97:115-22.

6 Xu X, Rijcken B, Schouten JP, et al. Airways responsiveness and development and remission of chronic respiratory symptoms in adults. Lancet 1997;350:1431-4.

7 Sunyer J. Urban air pollution and chronic obstructive pulmonary disease: a review. Eur Respir J 2001;17:1024-33.

8 Sandford AJ, Pare PD. Genetic risk factors for chronic obstructive pulmonary disease. Clin Chest Med 2000;21:633-43.

9 Balmes J, Becklake M, Blanc P, et al. American Thoracic Society statement: Occupational contribution to the burden of airway disease. Am J Respir Crit Care Med 2003; 167:787-97.

10 Churg A, Wright JL. Airway wall remodeling induced by occupational mineral dusts and air pollutant particles. Chest 2002;122:306-9S.

11 Dahl M, Tybjaerg-Hansen A, Vestbo J, et al. Elevated plasma fibrinogen associated with reduced pulmonary function and increased risk of chronic obstructive pulmonary disease. Am J Respir Crit Care Med 2001; 164:1008-11

12 Siafakas NM, Tzortzaki EG. Few smokers develop COPD. Why? Respir Med 2002;96:615-24.
13 Davison AG, Fayers PM, Taylor AJ, et al. Cadmium fume inhalation and emphysema. Lancet 1988;1:663-7.

14 Armstrong BG, Kazantzis G. The mortality of cadmium workers. Lancet 1983:1:1425-7.

15 Snider GL, Hayes JA, Korthy AL, et al. Centrilobular emphysema experimentally induced by cadmium chloride aerosol. Am Rev Respir Dis 1973; 108:40-8.

16 Hendrick DJ. Occupational and chronic obstructive pulmonary disease (COPD). Thorax 1996:51:947-55.

17 National Center for Health Statistics. Plan and operation of the Third National Health and Nutrition Examination Survey, 1988-1994. Vital and Health Statistics 1994;1(82).

18 Anon. Executive summary of the clinical guidelines on the identification, evaluation, and treatment of overweight and obesity in adults. Arch Intern Med 1998;158:1855-67.

19 American Thoracic Society. Standardization of spirometry-1987 update. Statement of the American Thoracic Society. Am Rev Respir Dis 1987; 136:1285-98.

20 Hankinson JL, Odencrantz JR, Fedan KB. Spirometric reference values from a sample of the general US population. Am J Respir Crit Care Med 1999; 159:179-87.

21 Pauwels RA, Buist AS, Calverley PM, et al. Global strategy for the diagnosis, management, and prevention of chronic obstructive pulmonary disease. NHLBI/WHO Global Initiative for Chronic Obstructive Lung Disease (GOLD) workshop summary. Am J Respir Crit Care Med 2001;163:1256-76.

22 Paschal DC, Burt V, Caudill SP, et al. Exposure of the US population aged 6 years and older to cadmium: 1988-1994. Arch Environ Contam Toxicol 2000;38:377-83.

23 Mason HJ, Williams NR, Morgan MG, et al. Influence of biological and analytical variation on urine measurements for monitoring exposure to cadmium. Occup Environ Med 1998;55:132-7.

24 Bernert JTJ, Turner WE, Pirkle JL, et al. Development and validation of sensitive method for determination of serum cotinine in smokers and nonsmokers by liquid chromatography/atmospheric pressure ionization tandem mass spectrometry. Clin Chem 1997;43:2281-91.

25 SAS Institute I. SAS language: reference. Version 6. Cary, NC: SAS Institute, 1990.

26 Shah BV, Barnwell BG, Bieler GS. SUDAAN user's manual, Release 7.5. Research Triangle Park, NC: Research Triangle Institute, 1997.

27 Nordberg GF, Kjellstrom T. Metabolic model for cadmium in man. Environ Health Perspect 1979;28:211-7.

28 Lewis GP, Coughlin LL, Jusko WJ, et al. Contribution of cigarette smoking to cadmium accumulation in man. Lancet 1972;1:291-2.

29 Mussalo-Rauhamaa H, Leppanen A, Salmela SS, et al. Cigarettes as a source of some trace and heavy metals and pesticides in man. Arch Environ Health 1986;41:49-55.

30 Connally G. 1999 Massachusetts Benchmark Study. Boston, MA: Massachusetts Tobacco Control Program, 2000.

31 Watanabe T, Koizumi A, Fujita $\mathrm{H}$, et al. Cadmium levels in the blood of inhabitants in nonpolluted areas in Japan with special references to aging and smoking. Environ Res 1983;31:472-83.

32 Elinder CG, Friberg L, Lind B, et al. Lead and cadmium levels in blood samples from the general population of Sweden. Environ Res 1983;30:233-53.

33 Hirst RN Jr, Perry HM Jr, Cruz MG, et al. levated cadmium concentration in emphysematous lungs. Am Rev Respir Dis 1973;108:30-9.

34 Paakko P, Kokkonen P, Anttila S, et al. Cadmium and chromium as markers of smoking in human lung tissue. Environ Res 1989;49:197-207.

35 Lewis GP, Jusko WJ, Coughlin LL. Cadmium accumulation im man: influence of smoking, occupation, alcoholic habit and disease. J Chronic Dis 1972;25:717-26.

36 Roels H, Lauwerys R, Buchet JP, et al. Significance of urinary metallothionein in workers exposed to cadmium. Int Arch Occup Environ Health 1983:52:159-66.

37 Lauwerys RR, Roels HA, Buchet JP, et al. Investigations on the lung and kidney function in workers exposed to cadmium. Environ Health Perspect 1979;28:137-45.

38 Hart BA, Potts RJ, Watkin RD. Cadmium adaptation in the lung - a doubleedged sword? Toxicology 2001;160:65-70.

39 Tatrai E, Kovacikova Z, Hudak A, et al. Comparative in vitro toxicity of cadmium and lead on redox cycling in type II pneumocytes. J Appl Toxicol $2001 ; 21: 479-83$.

40 Chowdhury P, Louria DB, Chang LW, et al. Cadmium-induced pulmonary injury in mouse: a relationship with serum antitrypsin activity. Bull Environ Contam Toxicol 1982;28:446-51

41 Jarup L, Bellander T, Hogstedt C, et al. Mortality and cancer incidence in Swedish battery workers exposed to cadmium and nickel. Occup Environ Med 1998:55:755-9.

42 Thun MJ, Schnorr TM, Smith $A B$, et al. Mortality among a cohort of US cadmium production workers: an update. J Natl Cancer Inst 1985;74:325-33.

43 Sorahan T, Lancashire RJ. Lung cancer mortality in a cohort of workers employed at a cadmium recovery plant in the United States: an analysis with detailed job histories. Occup Environ Med 1997;54:194-201.

44 Bjorkman L, Vahter M, Pedersen NL. Both the environment and genes are important for concentrations of cadmium and lead in blood. Environ Health Perspect 2000; 108:719-22.

45 Beyersmann D, Hechtenberg S. Cadmium, gene regulation, and cellular signalling in mammalian cells. Toxicol App/ Pharmacol 1997; 144:247-61.

46 Klaassen CD, Liu J, Choudhuri S. Metallothionein: an intracellular protein to protect against cadmium toxicity. Annu Rev Pharmacol Toxicol 1999:39:267-94. 